伊豆青ケ島島民にみられた肉の好き嫌いについて

坂口登

状況

昭和 29 年 11 月、八丈島南方洋上の小坬島。青ケ 島を調查した一団 (人類誌： 64 巻 1,2 号) 飞参加 したわたくしは、調査をすすめてゆく途上、島民 のかなり多くのものが、肉類を嫌い、また肉をた ベるとジンマシン（らしいもの）や腹痛、下痢。 嘔吐などをお乙すととを知つた。島から帰つたわ たくしは、直ちに東京都下、小金井町で同様の調 查を試みた。乙れらの結果は、その解明までにほ どとおいとしてあ、事実として興味ぶかく思われ た。不慮の事故のためその資料を焼失し、発表を あきらめていたとてろ、最近になつてメモをとつ てあつた紙がみつかつたので、こてに簡単な報告 をしておきたい。

約 380 名の島民のうち 231 名について、食べも のの好き嫌い、及びその理由について質极るとと ができた。たとえば人参が嫌いであるとか、塩か らが嫌いであるとか、どてにであみられるような あのを除くと、肉類を好ま好者が意外飞多かつた。 しかし魚が嫌いだと応える者は 1 人 2 人にとよ゙ま つた。(この島は古くから漁業が盛んで、魚はよ く食べた。一方、肉食の習慣は新らしく、こんに ちでむそ机ぼ多くないようにみうけられる。）

青ケ島で食べられている肉は、ふつう牛、豚、 にわとりである。これらに牛乳を加えて、好き嫌 いの状態をまとめると表の如くである。

にわとりの肉が嫌いだという者は、例外なく牛 肉も豚肉も嫌いである。そしてその逆の例はみら れない。また豚肉より牛肉を嫌うあのが明らかに 多い。(ジンマシンは一般にとり肉より、牛肉や 豚肉によつてよく扟ると云われている。）そし て肉を好ま媎の殆んどが、牛乳あ好きでない。 しかし牛乳でジンマシンになるととは少ないよう である。

肉を好まぬ理由とその考察

なぜ嫌いか、という質問にたいする応えは次の 如くであつた。たぐし、小中学生についてはこれ

\begin{tabular}{|c|c|c|c|c|c|c|c|}
\hline & \multicolumn{2}{|c|}{ 成人 } & \multicolumn{2}{|c|}{ 小中学生 } & \multicolumn{2}{|c|}{ 合計 } \\
\hline & & 男 & 女 & 男 & 女 & 男 & 女 \\
\hline \multirow{5}{*}{$\begin{array}{l}\text { 肉 } \\
\text { 類 } \\
\exists \\
\neq \\
\text { ₹ } \\
ウ \\
\text { モ } \\
\text {, }\end{array}$} & 牛、豚、鶏肉 & 0 & $11^{\mathrm{a}}$ & 1 & 1 & 1 & 12 \\
\hline & 牛、豚肉 & $13^{b}$ & 24 c & 6 & 8 & 19 & 32 \\
\hline & 牛肉ノミ & $7^{\mathrm{d}}$ & $3^{\mathrm{e}}$ & 1 & 5 & 8 & 8 \\
\hline & 豚肉ノミ & 0 & $1^{\mathrm{f}}$ & 0 & 0 & 0 & 1 \\
\hline & 小 計 & 20 & 39 & 8 & 14 & 28 & 53 \\
\hline \multirow{5}{*}{$\begin{array}{l}\text { 余ナ } \\
\text { ス } \\
\text { ₹ } \\
\text { デ }\end{array}$} & 牛乳ノミ & 2 & 5 & 5 & 7 & 7 & 12 \\
\hline & $\begin{array}{l}\text { 牛:豚肉 } \\
\text { 余リスカヌ }\end{array}$ & $2^{g}$ & $4^{\mathrm{h}}$ & 0 & 0 & 2 & 4 \\
\hline & 小 計 & 4 & 9 & 5 & 7 & 9 & 16 \\
\hline & $\begin{array}{l}\text { 肉キライデ } \\
\text { ナイ }\end{array}$ & $53^{\mathrm{i}}$ & $32^{\mathrm{j}}$ & 24 & 16 & 77 & 48 \\
\hline & & 77 & 80 & 37 & 37 & 114 & 117 \\
\hline
\end{tabular}

を質せなかつた。表中の数字に付したアルファべ ット記号の順に記るしてゆく。（理由についての 分類は、あくまであ便宜的なむのであり、また調 査の途中から設定された項目あある。）

a. 11名中、ジンマシンになるから………1 名 体が変になる…………………1 名 信心之関係あると思わ机る者 6 名

(みて……5 名) 20才頃から嫌になつた………1名 とにかく媒い……………....2 名

b. 13名中、ジンマシン、腹痛……………8 名 信心………………………5 5 名

（舎人………3 名）

c. 24 名中、ジンマシン、腹痛……………9 名 信心…………………………7 7 名

(みて………6 名)

とにかく嫌い…………….... 3 名

不明…………………………5 名

d. 7 名中、ジンマシン……………….... 2 名

（信心するもの……1名）

くさいから（舎人）………1名 牛を扱つているから…………1名 
不明…… 3 名

e. 3 名中、

$$
\text { とにかく嫌い }
$$

1 名

f. 1 名、不明

g. 2 名中、

$$
\text { とにかく嫌い........................ } 3 \text { 名 }
$$

h. 4 名中、ジンマシン………………... 1 名 とにかく嫌い………………... 3 名

i. 53名中、時㧍りジンマシンや腹痛が㧍てる 者、またかつてそうであつた者が 相当数（ 7 名以上）ふくまれる。 53 名中、舎人 3 名。

j. 32 名中、子供の頃は肉は嫌いであつた者 3 名がふくまれる。

以上で明らかなでとく、肉を食べてジンマシン らしい症状を呈する者や腹痛、下疮、嘔吐をおこ す者が、成年男女の約 $15 \%$ をしめて、異常に多 い。乙れが何故であるか、結局つきとめることは できなかつたが、考えられる原因を一応あげてみ よう。ジンマシンができると云つた者のうちの 1 人は、かつて東京に行つた時. 肉を食べたが別状 なかつた、と述べている。そてでこの島の肉その あのを先づ調べてみる必要がある。島の肉は、濖 殺して直ちに食用に供され、その処理過程むや〉 変つたところがある。しかし、われわれ調查団 20 余名は、たびたびこの肉を食べる機会をあつたが。 20 日間の滞在中 1 人としてそのため纪変調をきた した者はなかつた。

次に島では主食として穀物のほかに、かなり多 くのサッマイモを食べている。水は天水を利用 し、塩分を多く含むむのと考えら机る。てのよう な栄養が異常な体質をつくりあげるととも考えら れる。

ジンマシン、腹痛とは別に、信心をしている者 の多くが、即ち舎人 (男子) では 7 名中 4 名。み
こ（女子）では11名全部が肉を嫌い、しかすその 程度がつよい。(島の宗教はいわ沛る哠術に近い 性質をもつあののでとくみうけられた。）しかし これは、信心をしているから肉を食べないという ようなものではない。即ち戒律の如きあのではな い。信心を始める前から嫌いだつた人、信心をは じめる頃からなんとなく嫌いになつた人など様々 で、特に前者が多いのである。とあかく、舎人や みこになるような気質と肉嫌いとは強い関係を持 つと思われるが、乙れをそのまま青ケ島の肉嫌い の解明に結びつけることはできないであろう。

小金井町との比較

東京都下小金井町（現在は市）は、まだ農家が 多く残り、一方では都会生活者の住宅地としても 拓けつつあつた。青ケ島調査の直後、わたくしは この町の中学生を通じて、町民約 250 名につき、 青ケ島とほメ゙同じ調査をアンケートにより試み た。ここでは肉を好ま好者が、男子で $16 \%$ 以下、 女子では $30 \%$ 以下である。青ヶ島では小。中学 生も含めて、男子 $25 \%$ 。女子 $45 \%$ となる。両者 の間にかなりの差があるが、とあに女子の方が明 らかに多い。概して食物の好き嫌いは男子より女 子に多く見られるむのらしいが、上記の事実につ いて筆者はむしろ、熱帯及び亜熱帯地方にしばし ばみられる肉のタブーが、一般に女子に対してよ り㛜しいととを連想するものである。

魚を嫌うものは、小金井町に扔いても亦。獣肉 に較べてはるかに少なかつた。

年令的にみると、小金井町では20才以下で高率 を示し、特に女子ではそれが著るしいが、青ケ島 では逆に男女とも20才以上に就いて著るしい。

以上。再調査の機会を期待しつつ、いくつかの 問題点を挙げたつむりである。

(日本大学医学部解剖学教室) 


\section{Distaste for and Abnormal Reactions to Meat on Aogashima Island}

\section{Noboru SAKAGUCHI}

Of 231 inhabitants of Aogashima Island which is located to the south of Hachijojima Island, $25 \%$ of males and $45 \%$ of females have distaste for meat; in Koganeimachi of Tokyo where I investigated just after working at Aogashima, 16\% of males and $30 \%$ of females have distaste for meat. The peoples of both places, however, do not dislike fish so much.

Thus in Aogashima, the tendency toward disliking meat is unusually strong. Furthermore there are many, $15 \%$ of the islanders, who suffer from urticaria, abdominal pains, diarrhoea and vomiting after eating meat. And four of seven shajins and all of eleven mikos have rather stronger distaste for meat. (shajin or miko means a man or a woman who is in ser- vice of the ritual of a shrine. They seem to have peculiar mental characters in Aogashima.)

It may be safe to say that females have more distaste for meat than males. (This interests us when we can often see meat taboos especially for women of primitive societies in the tropical and subtropical zones.) The ratio of those females who do not like meat increases when they are above twenty years of age in Aogashima, whereas the ratio reverses in Koganeimachi.

Department of Anatomy, Faculty of Medicine, Nihon University 